\title{
2 次元乱流噴流速度場の多点同時計測と時空間構造解析 \\ The multi-point simultaneous measurement of streamwise velocity and the analysis of spatio-temporal structure in a turbulent plane jet
}

\author{
正 酒井康彦 (名大工) $\bigcirc$ 学 田中伸彦 (名大院) \\ 学 山本睦 (名大院) 櫛田武広 (名大工)
}

Yasuhiko SAKAI and Takehiro KUSHIDA, Dept. of Mechano-Informatics and Systems, Nagoya University, Furo-cho, Chikusa-ku, Nagoya, 464-86031

Nobuhiko TANAKA and Mutsumi YAMAMOTO, Graduate School of Nagoya University

Key Words: Turbulent plane jet, Multi-point measurement, POD, Coherent structure

1 はじめに 本研究では基本的で取り扱いやすく，かつ応用 上重要な 2 次元噴流を取り上げ，その自己保存領域にお忖る乱 流構造について調べた．実験として，I 型熱線ブローブによる 21 点同時測定を行い，その得られた実験データに KL 展開と Fourier 変換を組み合わせた解析を適用した ${ }^{(1),(2),(3)}$. KL 展 開は固有直交分解 (POD) 上呼ばれ，客観的に乱流の構造を抽 出寸るための方法として用いられている ${ }^{(3)}$. 本報では, この解 析法によって得られた固有值, 固有関数を用いてパワースペク トル, 瞬時速度場の再構成を行い, オリジナルの分布と比較し, 再構成された流れ場の特徵について調べた。

2 実験装置と条件 本実験では, 出口高さ $d=12 \mathrm{~m}$, アスペク 卜比 19.7 のノズルから $U_{0} \sim 20 \mathrm{~m} / \mathrm{s}$ で空気を静止流体中に噴出 させる。この時の出ロレイノルズ数 $\operatorname{Re}\left(=U_{0} d / \nu\right)$ は 16,000 で ある. 噴流中心軸に垂直な方向 $\left(x_{2}\right)$ に I 型熱線プローブを 21 本並べて 21 チャンネル同時測定を行った。各ブローブの間隔 は 7.5mm と一定で, 测定断面は $x_{1} / d=10.0,15.0,20.0,25.0$, 30.0, 35.0, 40.0 の 7 断面である.

3 実検結果 平均速度分布と速度 r.m.s. 值分布を調べた結果, 平均速度分布は噴流外縁部を除き, 経験的近似曲線として知ら れている Gauss 分布とほぼ一致し, 速度 r.m.s. 值分布も過去の 研究者の分布と良い一致を示していて, 本研究に打ける多点同 時測定実験のデータが信頼できるものであることが確諗できた。

\section{4 解析結果}

4.1 スペクトルの再構成 KL 展開と Fourier 変換を組み合 わせた解析により得られた固有值と固有関数から， $x_{1} / d=$ $20.0, x_{2} / b=0.5$ におけるパワースベクトルの再構成を行った 結果を図 1 に示寸. First two modes は, 最初の 2 つの基底 (固 有関数)により再構成されたことを示寸。また, 図中のパーセ ントの值は, 再構成されたスペクトルのオリジナルのスベクト ルに対寸る㟢与率を表している．オリジナルでは， $-5 / 3$ 乗則の 領域が現れており, さらに, 高周波数領域に 2 次元乱流の特徵 である-3 乗則の領域も見られる。再構成されたスペクトルは, First four modes や First six modes では-5/3 乗則の領域が見 られる. 特に, First six modesではオリジナルの分布とほぼ 同じ形状をしていることが分かる。一方, First one mode や First two modes では，-5/3 乗則の領域は見られず，上り早く 減衰している。これは，KL 展開が乱れエネルギ一の大きいと ころから再構成していくためであり，図からも First one mode や First two modes の分布は高周波数に向かうにつれて，才リ
ジナルの分布との差が大きくなっていく様子が確認できる.

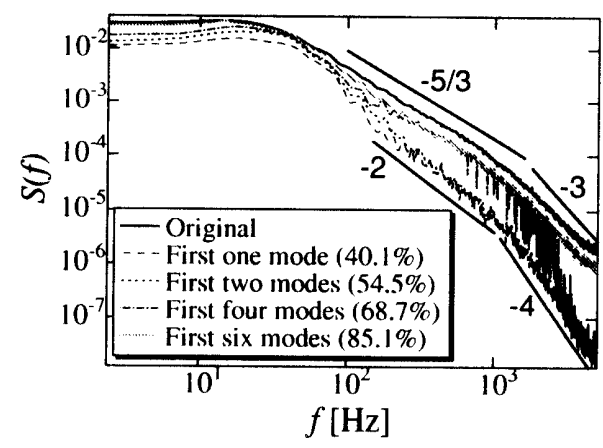

Fig. 1: POD reconstructed spectra $S(f)$ at $x_{1} / d=20.0, x_{2} / b=0.5$

4.2 速度場の再構成 この解析により得られたランダム倸数 と固有関数から， $x_{1} / d=20.0$ における瞬時速度場 $\sigma$ 再構成を 行った. オリジナルの分布と比較寸ると, 細かい変動がなくなっ ている様子が分からた。 また，KL 展開のみを用いて同じ条件 で再構成を行った分布では, 高速の流体塊が中心軸の両側にほ ぼ交互に分布している様子が確認できた。これは, Antonia et al. ${ }^{(4)}$ が述べた 2 次元噴流の大きなスケールの構造は互いに逆 回転寸る渦構造が交互に分布しているということと対応してい ると思われる。しかし，KL 展開と Fourier 変換を組み合わせた 解析で再構成した分布ではこのような構造を抽出することがで きなかった。この理由は，KL 展開のみの場合は，KL 展開の特 性により適用した乱流場から最もエネルギ一の大きな構造を抽 出寸ることができるのに対して，KL 展開と Fourier 変換を組 み合わせた場合では，周波数方向には一様性を仮定して Fourier 変換を行っているため，エネルギ一的には小さい高周波数での 固有関数の影響もあるためと考えられる。

\section{参考文献}

(1) Gordeyev S. V., J. Fluid Mech., Vol.460, pp.349-380, (2002),

(2) George, W.K., KLUWER ACADEMIC PUBLISHERS, pp.75-90., (1990),

(3) Delville, J., KLUWER ACADEMIC PUBLISHERS, pp.7590, (1991),

(4)Antonia R. A., J.Fluid.Mech., Vol.134, pp.49-66, (1983), 